\title{
Comparison between Emotional Intelligence and Aggression among Student Teachers at Secondary Level
}

\author{
Sajna Jaleel*, Alie Molly Verghis \\ School of Pedagogical Sciences, Mahatma Gandhi University, Kottayam, India
}

Copyright $(2017$ by authors, all rights reserved. Authors agree that this article remains permanently open access under the terms of the Creative Commons Attribution License 4.0 International License

\begin{abstract}
The study explored the relationship between emotional intelligence and aggression among teacher trainees at secondary level. The hypothesis formulated for the study was, there is no significant relationship between Emotional Intelligence and aggression of teacher trainees at secondary level. The method adopted for the study was descriptive survey, which was carried out on a sample of 90 student teachers at secondary level, selected purposively. The tools used for data collection were, 1) Emotional Intelligence Inventory by S.K. Mangal and Shubhra Mangal designed for college and university students for the measurement of their emotional intelligence (total as well as separately) in respect to four areas or aspects of emotional intelligence namely, intrapersonal awareness, interpersonal awareness, intra personal management and interpersonal management. 2) Aggression Scale by Dr. G.P. Mathur and Dr. Rajkumari Bhatnagar. The statistical techniques used for the study are, Karl Pearson Product Moment coefficient of correlation and Analysis of Variance. The results revealed that $44 \%$ of the teacher trainees have average emotional intelligence, $26 \%$ have high EI, whereas, $24 \%$ have low EI. Only $6.66 \%$ of teacher trainees have low aggression. 44\% have average aggression and almost half of the sample has high aggression. The computed value of coefficient of correlation between Emotional Intelligence and Aggression is not significant at .05 level. The computed value of coefficient of correlation between Emotional Intelligence and Aggression of teacher trainees coming from rural and urban areas is also not significant at .05 level.
\end{abstract}

Keywords Emotional Intelligence, Aggression

\section{Introduction}

Emotional Intelligence (EI) may be defined as the ability to perceive, understand and regulate one's emotions or another person's emotions [1-2]. Daniel Goleman [3] in his famous book Emotional Intelligence: Why It Can Matter
More Than IQ, claims that only $20 \%$ of a person's success can be attributed to IQ. It is Charles Darwin who first recognized the importance of EI. Later, Peter Salovey and John Mayer did extensive researches on the topic. Researches proved that emotional intelligence and social intelligence are more effective predictors of a person's success in life. Emotional intelligence describes the ability, capacity, skill, or self-perceived ability to identify, assess, and manage the emotions of one's self, of others, and of groups. People who possess a high degree of emotional intelligence know themselves very well and are also able to sense the emotions of others. They are affable, resilient, and optimistic [4].

On the contrary, aggression can be damaging at personal and social level because aggressive individuals experience difficulty interpreting situations as a result of that they become violent or isolated [5]. Aggression is a disorganizing emotional response. A sufficiently good number of Psychologists, Bandura and Walters [6], Dollard et al. [7] have worked on different aspects of aggression.

Research evidence shows that there exist a significant negative correlation between emotional intelligence and aggression. Liau et al. [8] has demonstrated EI to be negatively correlated with aggression and delinquency. Emotional intelligence skills are important resources for enhancing students' learning, success, attitudes, academic performance and psychological well-being [9]. Another study conducted by Formica [10] revealed a similar negative correlation between aggressive behaviour and the Mayor Emotional Intelligence Scale. College students' self-reported account of drug abuse and aggressive behavior correlated negatively with Mayor Salovey Caruso Emotional Intelligence Test, (2000). Brackett et al. [11] in their study found that low level of emotional intelligence among adolescents leads to adolescent substance and illegal drug abuse, poor interpersonal relationship, high level of aggression, and physical fights. Low levels of EI have been correlated with some forms of mental illness, including depression, aggression, borderline personality disorder and difficulties in processing emotional information [12].

Apart from its contribution to academic success, a person 
with high emotional intelligence is also said to function better as a worker, being able to work under pressure, and contribute to organization's productivity. It is becoming more evident that employers nowadays are no longer looking for employees with good grades alone but they are more interested in applicants who can meet the demands of a working world and adapt to the forever changing climate and needs of their organization. This is especially true in professions that require the employees to be highly emotionally intelligent.

\section{Need and Significance of the Study}

Education is considered as an instrument for fostering the creation of good citizens who are capable of understanding themselves, having a capacity to explore, to examine his/her inner strength and going beyond it to work for the uplifting the society. Teaching profession is very demanding profession. A good teacher should be sensitive to the demands- physical, emotional and intellectual, of the children who are in front of her. An emotionally intelligent teacher will be able to handle his/her situations effectively and help young people feel connected and self-confident. Sutton and Wheatley as cited in Kremenitzer and Miller [13] (p. 107) argue that "emotions are an integral part of a teacher's job and have an impact on teacher effectiveness, behavior, cognition, and motivation". Nelson, Low and Nelson [14] (p. 2) also posit that teachers can "effectively deal with the pressures and demands of daily life and work" by developing and capitalizing on their emotional intelligence skills. Therefore, due to the nature and demands involved in teaching, teachers should build on and strive to acquire high level of emotional intelligence to stay relevant and effective in the line of education. Based on this discussion, it is clear that having high emotional intelligence gives an added advantage to individuals, may it be in educational pursue or career development.

Aggressive behaviour on the part of teachers will create a sense of ill feeling in children and destroy their self-esteem. This will lead to the creation of a group of children who are emotionally disturbed. Especially during the adolescent stage, this may lead to destructive and delinquent behaviours. So it is very important that students who are being trained for the teaching profession be aware of the importance of having good emotional intelligence.

The study aims at creating awareness among teacher trainees on their level of emotional intelligence in different areas and their aggression level. This will help them in making necessary changes and adjustments in their life and help them in being successful in their profession as well as their life.

\section{Objectives of the Study}

- To find out the level of Emotional intelligence among teacher trainees at secondary level.

- To find out the level of aggression among teacher trainees at secondary level.

- To study the difference between emotional intelligence among teacher trainees of rural and urban areas.

- To study the difference between aggression among teacher trainees of rural and urban areas.

- To study the relationship between Emotional Intelligence and aggression of teacher trainees from rural and urban areas.

\section{Hypothesis of the Study}

The present study formulated three null hypotheses for testing:

1. There is no significant relationship between Emotional Intelligence and Aggression of teacher trainees

2. There is no significant difference between emotional intelligence of teacher trainees from rural and urban areas.

3. There is no significant difference between aggression of teacher trainees from rural and urban areas.

4. There is no significant relationship between Emotional Intelligence and Aggression of teacher trainees from rural and urban areas.

\section{Methodology}

Sample: The study was correlational and exploratory, which was carried out on a sample of 90 teacher trainees, among which 36 are from urban area and 54 from rural area. Convenience sampling technique was used in the selection of the sample. The teacher trainees fall in the age range 21 to 25.

\section{Tools:}

1) Emotional Intelligence Inventory by S.K. Mangal and Shubhra Mangal [15] designed for college and university students for the measurement of their emotional intelligence (total as well as separately)

2) Aggression Scale by Dr. G.P. Mathur and Dr. Rajkumari Bhatnagar [16].

Karl Pearson Product Moment coefficient of correlation and $t$ test were employed for statistical analysis

Variables: The dependent variables of the study are Emotional Intelligence and aggression while the independent variable is the locality of the teacher trainees.

\section{Analysis of Data and Discussion of Result}

The analysis and interpretation of the data collected are given below 


\subsection{Level of Emotional Intelligence among Teacher Trainees}

Table 1. Percentage distribution according to the level of Emotional intelligence among teacher trainees

\begin{tabular}{|c|c|c|}
\hline Group & Count & Percentage \\
\hline Poor & 24 & 26.66 \\
\hline Average & 40 & 44.44 \\
\hline Good & 26 & 28.88 \\
\hline
\end{tabular}

It is clear from Table 1 , that $44 \%$ of the teacher trainees have average emotional intelligence. $26 \%$ have high EI. Whereas, $24 \%$ have low EI. This shows that methods for developing the EI of teacher trainees are necessary.

\subsection{Level of Aggression among Teacher Trainees}

Table 2. Percentage distribution according to the level of Aggression among teacher trainees

\begin{tabular}{|c|c|c|}
\hline Group & Count & Percentage \\
\hline Low & 6 & 6.66 \\
\hline Average & 40 & 44.44 \\
\hline High & 44 & 48.88 \\
\hline
\end{tabular}

Analysis of Table. 2 reveals that only $6.66 \%$ of teacher trainees have low aggression. 44\% have average aggression and almost half of the sample has high aggression.

\subsection{Relationship between Emotional Intelligence and Aggression among Teacher Trainees at Secondary Level}

Table 3. Correlation between Emotional Intelligence and aggression among teacher trainees at secondary level- Total Sample

\begin{tabular}{|c|c|c|c|c|}
\hline Variables & $\mathbf{N}$ & Mean & SD & $\begin{array}{c}\text { Coefficient of } \\
\text { correlation, } \mathbf{r}\end{array}$ \\
\hline $\begin{array}{c}\text { Emotional } \\
\text { Intelligence }\end{array}$ & 90 & 64.44 & 9.595 & 0.089 \\
\hline Aggression & 90 & 197.24 & 25.15 & \\
\hline
\end{tabular}

The computed value of coefficient of correlation denotes an indifferent or negligible relationship [17]

\subsection{Difference between Emotional Intelligence Level of Teacher Trainees from Urban and Rural Areas}

Table 4. Difference between emotional intelligence of rural and urban teacher trainees

\begin{tabular}{|c|c|c|c|c|c|c|}
\hline Variable & Locality & N & Mean & SD & t value & p \\
\hline Emotional & Urban & 36 & 64.611 & 9.937 & \multirow{2}{*}{0.835} & \multirow{2}{*}{$\mathrm{P}>.05$} \\
\cline { 2 - 5 } Intelligence & Rural & 54 & 64.178 & 9.315 & & \\
\hline
\end{tabular}

The $\mathrm{t}$ value obtained is not significant at .05 level. Therefore the null hypothesis is accepted.

\subsection{Difference between Aggression Level of Teacher Trainees from Urban and Rural Areas}

Table 5. Difference between aggression rural and urban teacher trainees

\begin{tabular}{|c|c|c|c|c|c|c|}
\hline Variable & Locality & N & Mean & SD & t value & p \\
\hline \multirow{2}{*}{ Aggression } & Urban & 36 & 194.94 & 23.77 & \multirow{2}{*}{0.945} & \multirow{2}{*}{$\mathrm{P}>.05$} \\
\cline { 2 - 6 } & Rural & 54 & 195.32 & 28.496 & & \\
\hline
\end{tabular}

The $\mathrm{t}$ value obtained is not significant at .05 level. Therefore the null hypothesis is accepted.

\subsection{Relationship between Emotional Intelligence and Aggression among Teacher Trainees from Rural and Urban Areas}

Table 3. Correlation between Emotional Intelligence and aggression among teacher trainees from rural and urban areas

\begin{tabular}{|c|c|c|c|c|c|}
\hline Variables & Locality & N & Mean & SD & $\begin{array}{c}\text { Coefficient of } \\
\text { correlation, r }\end{array}$ \\
\hline \multirow{2}{*}{$\begin{array}{c}\text { Emotional } \\
\text { Intelligence }\end{array}$} & Rural & 36 & 64.18 & 9.31 & \multirow{2}{*}{0.126} \\
\cline { 2 - 5 } & Urban & 54 & 64.611 & 9.94 & \\
\hline \multirow{2}{*}{ Aggression } & Rural & 36 & 195.32 & 28.49 & \multirow{2}{*}{0.093} \\
\cline { 2 - 5 } & Urban & 54 & 194.94 & 23.77 & \\
\hline
\end{tabular}

The computed value of coefficient of correlation denotes an indifferent or negligible relationship [17] between emotional intelligence of rural and urban students. Similarly for aggression also the relationship is negligible.

\section{Findings and Discussion}

- Percentage analysis revealed that $44 \%$ of the teacher trainees have average emotional intelligence, $26 \%$ have high EI, whereas, $24 \%$ have low EI. This shows that methods for developing the EI of teacher trainees are necessary.

- Only $6.66 \%$ of teacher trainees have low aggression. $44 \%$ have average aggression and almost half of the sample has high aggression. This is an alarming condition. Aggressive nature among teacher trainees may be due to the circumstances in which they were brought up. However, this has to be reduced, so that they become good teachers.

- The computed value of coefficient of correlation denotes indifferent or negligible relationship [17]. This means there is negligible correlation between teacher trainees, emotional intelligence.

- On comparison of teacher trainees coming from rural and urban areas regarding Emotional Intelligence, negligible or indifferent relationship was seen. This means that locality do not influence the emotional intelligence of teacher trainees.

- On comparison of teacher trainees coming from rural and urban areas regarding Aggression, negligible or indifferent relationship was seen. This means that aggressive behaviour of teacher trainees is not due to the influence of locality. This points out to the necessity of conducting studies taking into consideration other variables that may influence aggressive bahaviour.

\section{Educational Implications}

- Effective training programmes for developing the level of emotional intelligence among teacher trainees has to be formulated 
- High aggression rate of prospective teachers has to be taken seriously and strategies for reducing aggressive tendencies should be employed.

- Orientation programmes on Emotional Intelligence and behavioural aspects should be organized.

- Emotionally intelligent people are amiable, resilient and optimistic. Creation of such a community should be the first priority in an educational programme.

- The emotional intelligence of teacher trainees should be developed as it has an effect on their personal and job performance.

- Teacher educators should help teacher trainees on how to understand and manage their emotions, how to motivate themselves and others and how to improve teamwork and leadership qualities.

- Counselling programmes should be arranged to ensure the emotional well-being of teacher trainees.

\section{Conclusions}

Based on the findings we can arrive at certain conclusions. Almost seventy percent of the teacher trainees have an appreciable level of emotional intelligence. While, the remaining $30 \%$ need some kind of intervention programmes to boost up their emotional intelligence level as it is very important for a budding teacher to have an adequate level of self-assessment and relationship management skills. In 50\% of the students the level of aggression is above average. This is alarming. Development of skills to control the aggression level is very much necessary. This is needed for efficiency in their profession and also for peaceful co-existence. The study shows that High Emotional intelligence and low aggression levels are having a highly dependable relationship. This leads to the necessity of developing the emotional intelligence among teacher trainees as they are being trained for a noble profession.

\section{REFERENCES}

[1] Mayer JD, Salovey P, Caruso D. Models of Emotional Intelligence. In Sternberg R, editor:: Handbook of intelligence. San Francisco: Jossey-Bass.2000; p. 92-117.

[2] Mayer JD, Salovey P. What is emotional intelligence? In Salovey P, Sluyter D (eds.) Emotional development and emotional intelligence: Educational implications; New York: Basic Books; 1997; p.3-31.

[3] Goleman D. Emotional Intelligence: Why it can matter more than IQ. New York: Bantam Books; 1995.
[4] Oliver S. Understanding and Developing Emotional Intelligence. Knowledge Solutions. June 2009, 49. Asian Development Bank.

[5] Calvete E, Orue I. Cognitive Schemas and Aggressive Behavior in Adolescents: The Mediating Role of Social Information Processing. The Spanish Journal of Psychology.2010; 13(1): 190-201.

[6] Bandura A, Walters RH. Social learning and personality development. New York: Rinehart, N. Y. 1963.

[7] Dollard J, Doob LW, Miller NE, Mowers OH, Sears RR. Frustration and Aggression. Conn: Yale University Press.1939.

[8] Liau, A K, Liau A, TeohWL, Liau, MTL. The case for emotional literacy: The influence of emotional intelligence on problem behaviors in Malaysian secondary school students. Journal of Moral Education. 2003. 32; 51- 66.

[9] Wong C, Wong P, Chau S. Emotional intelligence, students' attitude towards life and the attainment of education goals: an exploratory study in Hong Kong. New Horizons in education. Journal of education, Hong Kong teachers Association (HKTA); 2001. 44: 1-11.

[10] Formica S. Description of the Socio-emotional Life Space: Life qualities and activities related to emotional intelligence. Unpublished Senior Honors Thesis, University of New Hampshire, Durham, NH.1998.

[11] Brackett M A, Warner R M, Mayer J D. Emotional intelligence and its relation to everyday behaviour. Personality and Individual Differences. 2004. 36(6):1387-1402.

[12] Das P. P. P., Tripathy S. Role of Emotional Intelligence on Aggression: A Comparison between Adolescent Boys and Girls. Psychology and Behavioral Sciences. 2015. 4(1): 29-35. doi: 10.11648/j.pbs.20150401.

[13] Kremenitzer J. Emotional Intelligence ability and the teacher candidate. Paper presented at the annual meeting of the American

Association of Colleges for Teacher Education [updated 200 9,May25;cited2009December9]Availablefromhttp://www.all academic.com $/$ meta/p35510_index.html

[14] Nelson DB, Low GR, Nelson K. The emotionally intelligent teacher:

Atransformativelearningmodel.[2005;2009November29]Ava ilablefromhttp://www.tamuk.edu/edu/kwei000/research/artic les/article_files/emotionally_intelligent_teacher.pdf

[15] Mangal S K, Mangal S. Manual for Mangal Emotional Intelligence Inventory. Agra: National Psychological Corporation.2004.

[16] Mathur G P, Bhatnagar R. Manual for Aggression Scale. Agra: National Psychological Corporation. 2009.

[17] Garrett, H.E. Statistics in Psychology and Education. New Delhi: Paragon International Publishers. 2004. 